\title{
Establishment and Characterisation of a Porcine Rubulavirus (LPMV) Persistent Infection in Porcine Kidney Cells
}

\author{
By B. Hjertner, T. Linné and J. Moreno-López
}

Department of Veterinary Microbiology, Section of virology (Unit of Molecular Virology), Biomedical Centre, Swedish University of Agricultural Sciences, Uppsala, Sweden.

\begin{abstract}
Hjertner, B., T. Linné and J. Moreno-López: Establishment and characterisation of a porcine rubulavirus (LPMV) persistent infection in porcine kidney cells. Acta vet. scand. 1997, 38, 213-224. - Porcine rubulavirus (LPMV) can establish persistent infections in porcine kidney cells. Cell cultures characterised at passages 25 and 65 demonstrated haemadsorption, formation of syncytia, and a slower growth rate. The nucleoprotein (NP) and haemagglutinin-neuraminidase (HN) protein were present in all cells, although not to the same extent as in wild type infected cells. Incubation of the cell cultures with virus neutralising antibodies could not cure them from the infection. The cells were resistant to LPMV high multiplicity superinfection, but lysed rapidly upon infection with VSV. These cells thus fulfilled the criteria of a true persistent infection.

Viral particles were released into the medium from the persistently infected cells as measured by HA and infection of PK-15 cells with medium from the persistently infected cells. The infectious titer of the virus released from the persistently infected cells was 3 logs lower compared to wild type virus, the $\mathrm{HN}$ titer still being comparable. Virus released from the persistently infected cells was unable to cause a lytic infection in PK-15 cells, and showed a reduced ability to spread when compared to a LPMV lytic infection.
\end{abstract}

paramyxovirus; homolytic infection.

\section{Introduction}

The porcine rubulavirus LPMV (La-PiedadMichoacan-Mexico Virus) emerged in Mexico around 1980, where it has since been endemic. Mainly piglets are affected, showing severe nervous system disorders. Stillbirths, mummified foetuses and orchitis are among symptoms that have been described in older pigs (Stephano et al. 1988).

Identification of LPMV structural proteins revealed a relationship to the genus paramyxovirus (Sundqvist et al. 1990). Cloning and sequencing of the matrix (M) protein gene (Berg et al. 1991), the haemagglutinin-neuraminidase
(HN) protein gene (Sundqvist et al. 1992) and the phosphoprotein (P) gene (Berg et al. 1992) showed that LPMV is closely related to the recently classified rubulavirus group (Rima et al. 1995 ) consisting of mumps virus (MuV), simian virus 5 (SV5), parainfluenza virus type 2 (PIV-2) and type 4 (PIV-4). The amino acid identity to $\mathrm{MuV}$ proteins is around $40 \%$.

Several paramyxoviruses have the ability to establish persistent infections in vitro as well as in vivo (Randall \& Russell 1991). A number of features have been attributed to the establishment and maintenance of the persistent state. 
Subgenomic RNAs, that interfere with lytic virus replication and require helper virus for the maintenance of the persistent infection, is a common trait in in vitro persistence (Holland et al. 1980, Moscona 1991, Murphy et al. 1990, $\operatorname{Re} 1991)$.

LPMV cause an economically important viral disease in Mexico. Transmission of the disease to other countries is a risk and the possibility of persistently infected animals spreading the disease must be considered. The main source of the disease are subclinically infected pigs (Stephano et al. 1988), and retrospective analyses of pig sera before 1980 have been positive against LPMV, indicating its existence in the pig population before the first outbreak. Factors mediating persistence in vivo as well as in vitro must therefore be identified. In this report we describe, for the first time, a porcine rubulavirus (LPMV) persistent infection under cell culture conditions and its partial characterisation.

\section{Materials and methods}

Persistently infected cells

Persistent infection was established by infecting porcine kidney (PK-15) cells at a m.o.i. of 10 Fluorescence focusing units (Ffu) with an LPMV (1984) isolate that had been passaged 4 times in cell culture. After an extensive CPE the surviving cells (less than $5 \%$ of the monolayer) were subcultivated until confluent monolayers could be maintained. Aliquots of these cells were frozen (at passage 20). The cells were grown for another 40 passages and again aliquots were frozen (passage 60). For further analysis, frozen persistently infected (PI) cells were thawed and passaged 5 times (to passage 25 and 65 ) before analysis.

\section{Cells and virus}

All cells were grown at $37^{\circ} \mathrm{C}$ in Eagles modi- fied medium containing tricine, neomycin and $10 \%$ foetal calf serum. Culture doubling time was estimated from series of time laps photographs and the frequency of subcultivation. PK15 cells were infected with LPMV at a m.o.i. of 10 Ffu for comparison studies with the PI cells. Infections of cells with virus released from the persistently infected cells were done at a m.o.i. of $0.1 \mathrm{Ffu}$ because of the low infectious titer obtained. In this case the wild type infection was also done at $0.1 \mathrm{Ffu}$.

\section{Virus titration}

LPMV and virus from the PI cells were titrated by infecting PK-15 cells with serial 10 fold dilutions (repeated at least 5 times for each virus preparation) in 96 well plates. After 3 days, end point dilution was determined by immunofluorescence using the monoclonal antibody 29.9 against the NP protein as described later, and the titers were calculated in Ffu according to Reed \& Muench (1938).

\section{Monoclonal antibodies and antiserum}

Purified detergent inactivated LPMV was used to inject $\mathrm{Balb} / \mathrm{c}$ mice, followed by isolation of spleen cells and hybridoma selection according to Örvell (1984). One clone (32.11) produced an antibody capable of haemagglutination inhibition (HI), virus neutralisation and positive immunofluorescence of LPMV infected cells. By immunoprecipitation analysis or western blots of LPMV viral proteins, a polypeptide $(66 \mathrm{kD})$, corresponding to the haemagglutininneuraminidase protein, was detected. Another clone (29.9) produced an antibody capable of positive immunofluorescence of LPMV infected cells and recognizing a viral polypeptide $(68 \mathrm{kD})$, identified as the nucleoprotein, by immunoprecipitation or western blot analysis. The rabbit polyclonal antiserum against LPMV has been described elsewhere (Sundqvist et al. 1990). 
Haemadsorption (HAD) and haemagglutination ( $H A$ )

Cells were analysed by HA and HAD according to standard precedures (Dinter 1989) in 96 well trays using chicken erythrocytes.

\section{Incubation with virus neutralising antibodies}

PK-15 cells or PI cells were grown in 24 well trays with or without a virus neutralising antibody (32.11) at a concentration sufficient to neutralise 20 fold the amount of virus released from the PI cells. The cells were grown for a period of 5 weeks and subcultivated weekly. Half of the cells from each well were further incubated and the other half analysed for the presence of haemadsorbing activity by HAD.

\section{Interferon production}

The amount of interferon released into the medium of uninfected PK-15 cells and persistently infected cells was determined by the dissociation-enhanced lanthanide fluoroimmunoassay (DELFIA) described by Artursson et al. (1995).

\section{VSV infection}

Persistently infected (PI) cells were infected with $1 \times 10^{3} \mathrm{TCID}_{50}$ of vesicular stomatitis virus (VSV, New Jersey). The CPE was examined in a light microscope at $24 \mathrm{~h}$ post infection. A PK15 cell culture infected with VSV was used as positive control.

\section{Immunofluorescense}

Cell cultures were grown on tissue culture chamber slides (Lab tek) for 2 days and then fixed by the paraformaldehyde method as described by Harlow \& Lane 1988. Briefly, monolayers were incubated for $10 \mathrm{~min}$ in a $4 \%$ paraformaldehyde solution at room temperature. The monolayers were then permeabilised with $0.2 \%$ triton X-100 in PBS for 2 min at room temperature. The cells were incubated with monoclonal antibodies directed against the $\mathrm{HN}$ or NP proteins. After one hour at room temperature, FITC-conjugated rabbit anti mouse was added. After another hour at room temperature citifluor (UKC, CHEM. LAB.) was added, coverslips mounted, and the immunofluorescence pattern analysed and photographed.

\section{Superinfection and reinfection}

Persistently infected cells (passage 25 and 65) were superinfected with LPMV at an m.o.i. of $10 \mathrm{Ffu}$. PK-15 cells were infected with virus from the PI cells (passage 25 and 65) at an m.o.i. of $0.1 \mathrm{Ffu}$. Controls included mock infected PK-15 cells, LPMV infected PK-15 cells (m.o.i. of 0.1 and $10 \mathrm{Ffu}$ ), and PI cells (passage 25 and 65). Photographs were taken at $120 \mathrm{~h}$ post infection.

\section{Results}

Establishment of porcine rubulavirus persistently infected cells - growth rate and morphology

Infection of PK-15 cells with the porcine rubulavirus LPMV resulted in extensive CPE and cell destruction (Fig. 1B). However, a small percentage $(<5 \%)$ of the infected cells survived and could be subcultivated. The cell culture stabilised rapidly and could be grown to a confluent monolayer. The cell culture could be subcultivated at least 70 passages without any crisis. The growth rates of PI cell cultures at passages 25 and 65 were markedly reduced when compared to mock infected PK-15 cells. Under the conditions used here PK-15 cell cultures had a doubling time of around $20 \mathrm{~h}$, whereas the PI cell cultures had doubling times of around $40 \mathrm{~h}$. A limited CPE could be seen, mainly as syncytium formation, although no or very few cells were lysed (Fig. 1C, D). Syncytium formation resembled that which is seen during lytic infection, was most prominent in newly seeded or growing cultures, and could only infrequently be seen in confluent cells. 


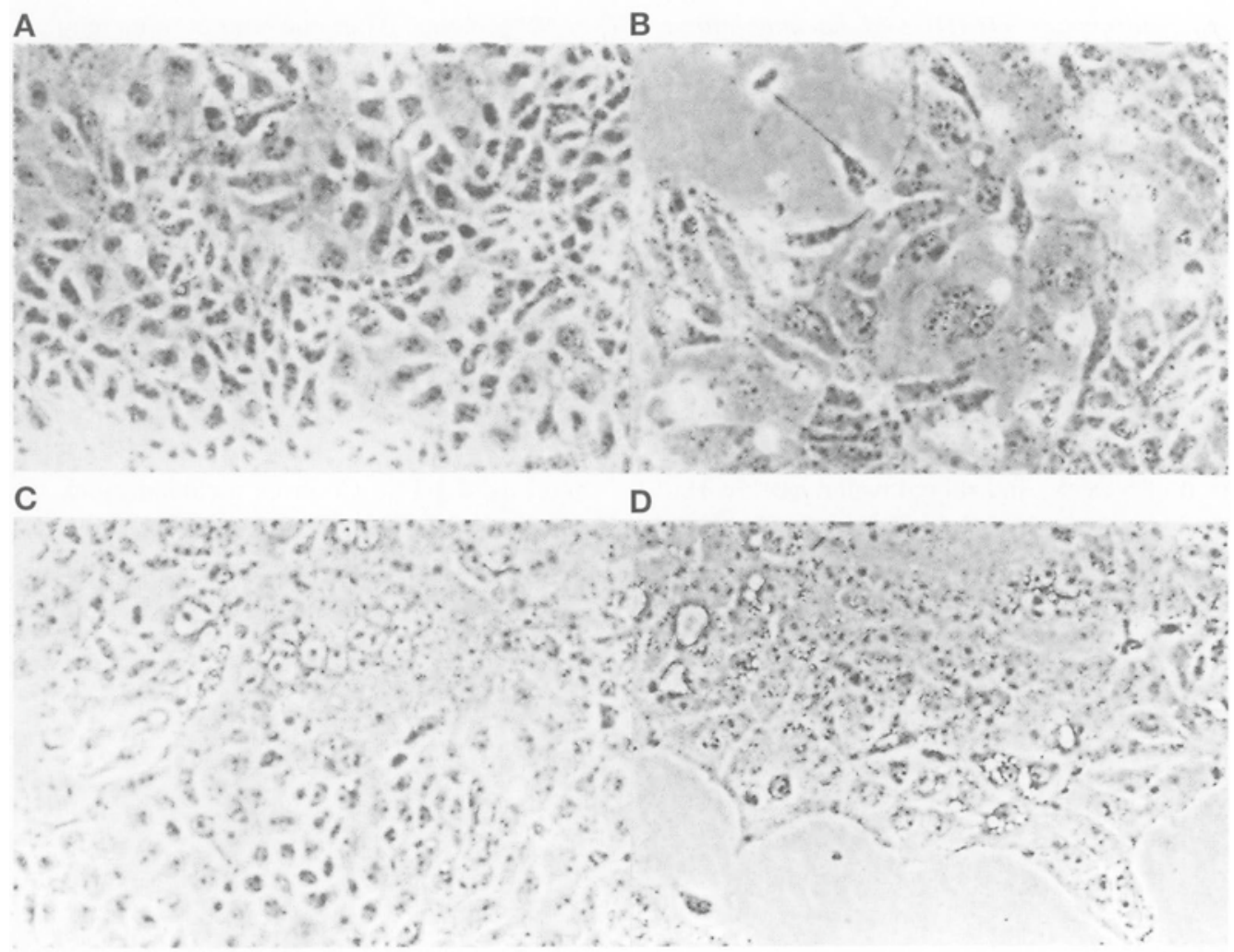

Figure 1. Morphology of LPMV wild type and persistently infected cells. Mock infected PK-15 cells (A). Wild type infected PK-15 cells (m.o.i. 1) at 48 h p.i. (B). PI cells at passage 25 (C) or 65 (D) at $48 \mathrm{~h}$ after subcultivation. Magnification $200 \times$.

\section{Analysis by haemadsorption (HAD)}

PK-15 cells do not adsorb chicken erythrocytes. However, both LPMV infected cells and the PI cell lines (passages 25 and 65) adsorbed red blood cells demonstrating the presence of viral haemadsorbing activity on the cell surface of the persistently infected cells (Fig. 2). In a typical wild type infection all, or almost all, cells showed HAD activity. The adsorption of erythrocytes to PI cells shows a variation in relation to time after subcultivation. Early after subcultivation all PI cells adsorbed erythrocytes (data not shown), but when the culture grew closer to confluence only $50 \%-75 \%$ of the cells adsorbed.
Analysis of virus antigens in PI cells by immunofluorescence

Two monoclonal antibodies (29.9 and 32.11) specific for the LPMV NP- and HN-proteins, respectively, were used to demonstrate the presence of viral proteins in the wild type infected and PI cells at passages 25 and 65 , but the staining was less intense than in the wild type infected cells. Both NP and HN proteins can be found in all the PI cells of both passages. The distribution of the NP protein in the LPMV infected (Fig. 3B) and PI cells (Fig. 3C, D) is characterised by a dot-like fluorescence in the cytoplasm of the infected cells. The HN protein 

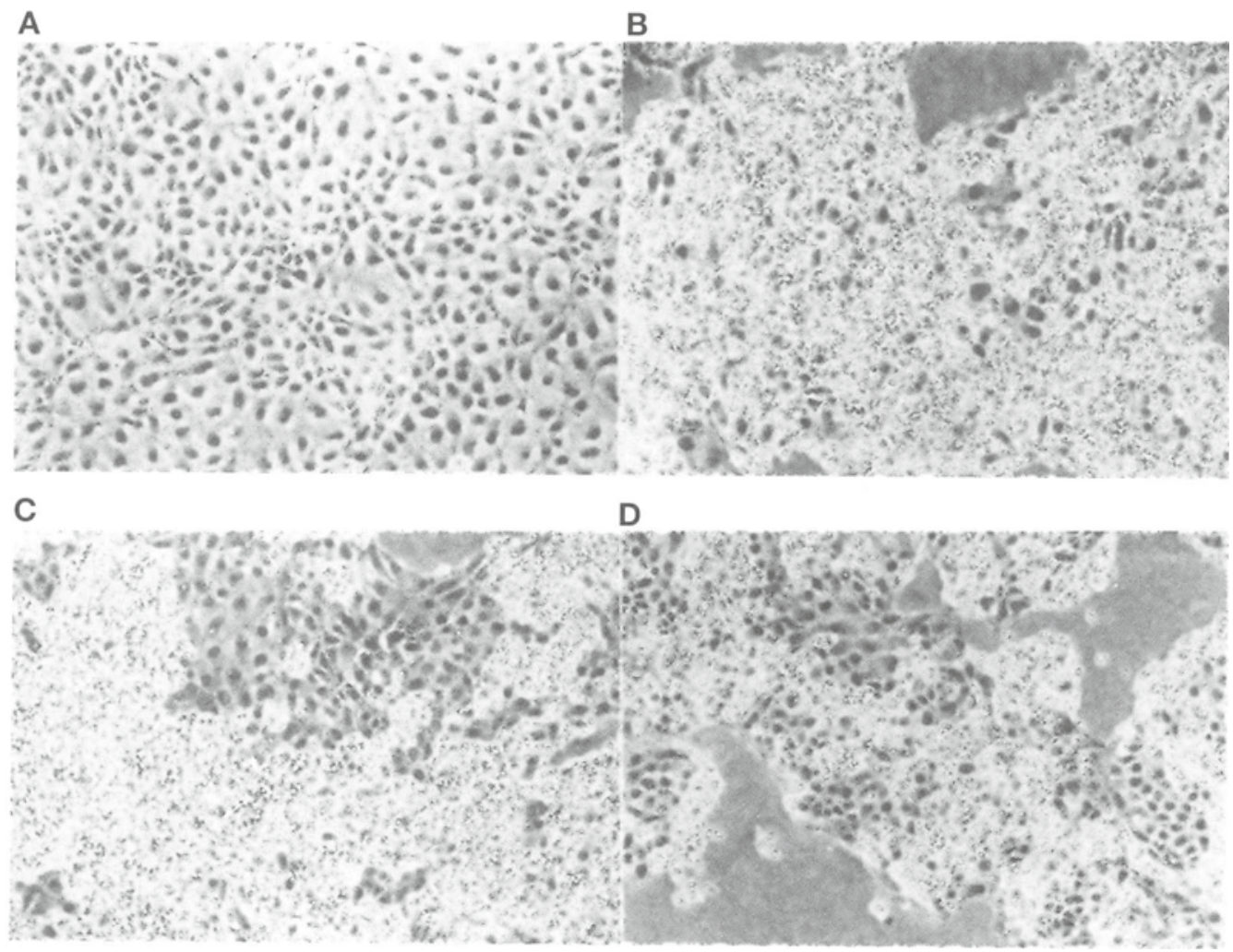

Figure 2. Adsorption of chicken erythrocytes to LPMV wild type and persistently infected cells. Mock infected PK-15 cells (A). Wild type infected (m.o.i. 1) PK-15 cells at $48 \mathrm{~h}$ p.i. (B). PI cells at passage 25 (C) and 65 (D) $48 \mathrm{~h}$ after subcultivation. Magnification $100 \times$.

was also detectable in cells of both wild type (Fig. 4B) and persistently (Fig. 4C, D) infected cells, although somewhat weaker than the NP protein.

\section{Superinfection of persistently infected cells}

One criterion of a truly persistently infected cell line is the resistance to superinfection by the homologous virus (Holland et al. 1980). A high multiplicity infection of PI cells (passages 25 and 65) with wild type LPMV, showed no increase of CPE or syncytium formation (Fig. 5), or increase in virus release as measured by HA or virus titration (data not shown). The lytically infected PK-15 cells showed extensive CPE and a high yield of infectious virus. There was no measurable interferon production in the PI cells and they were as sensitive as PK-15 cells to VSV infection, showing complete lysis of the cells overnight.

\section{Virus released from persistently infected cells}

The amount of virus produced and released into the medium of lytically infected cells and from the PI cells (passages 25 and 65) was assayed by $\mathrm{HA}$ and limiting dilution. Virus particles were slightly less abundant in supernatants from PI cells compared to LPMV wild type infected 
A

B

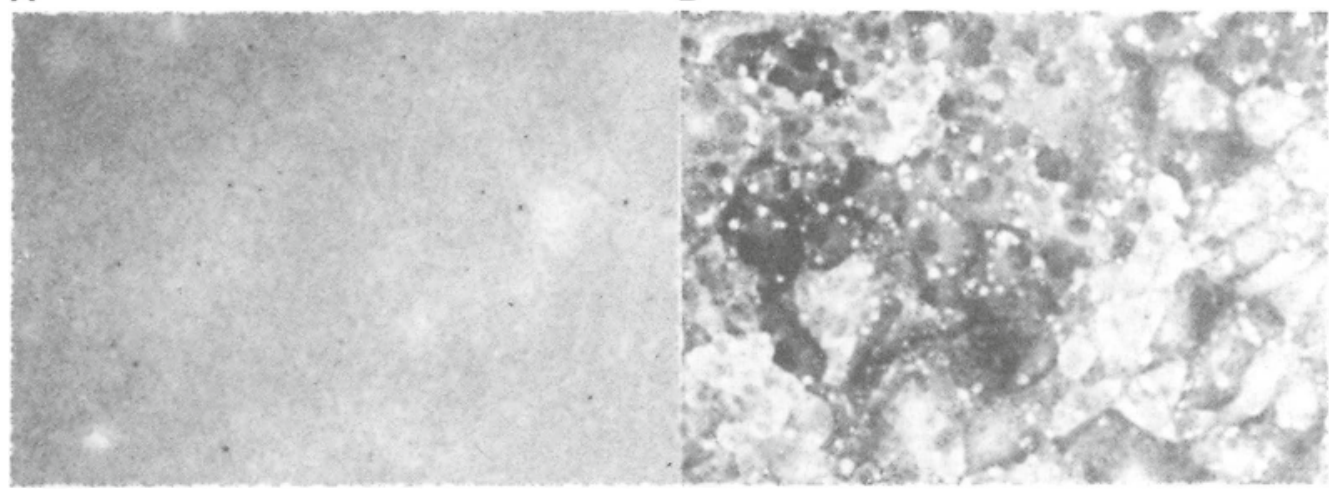

C

D

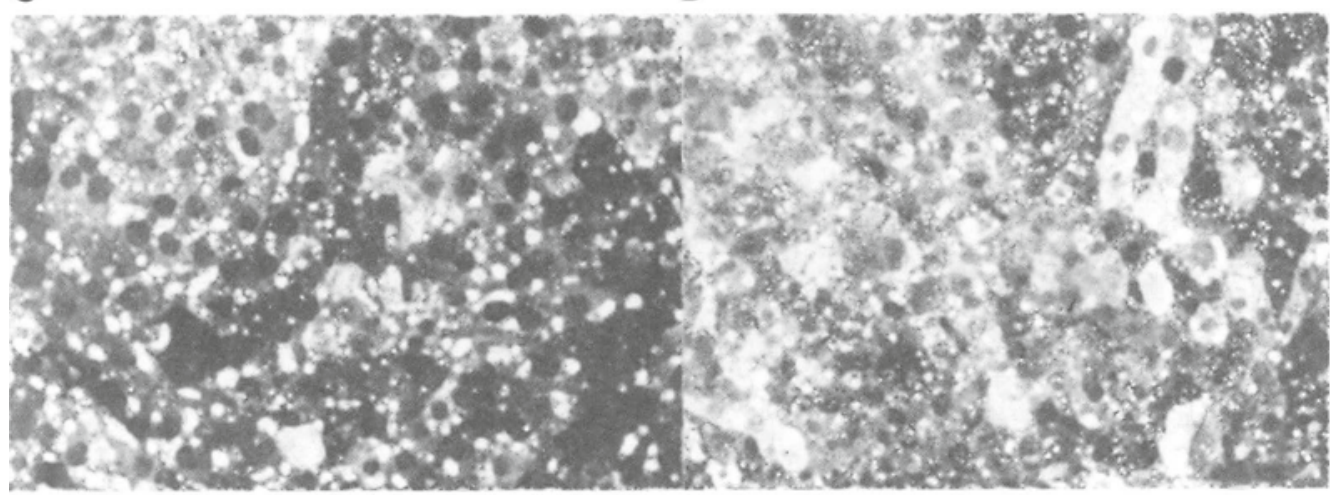

E

$\mathbf{F}$

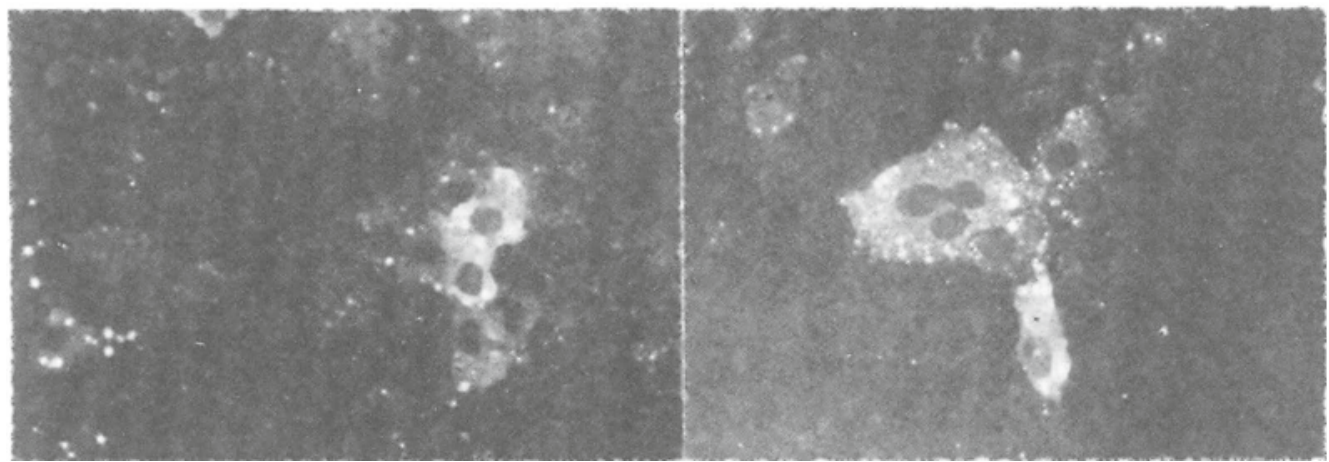

Figure 3. Detection of nucleoprotein (NP) in LPMV wild type and persistently infected cells by immunofluorescence. Mock infected PK-15 cells (A). Wild type infected ( 0.1 m.o.i.) PK-15 cells at $48 \mathrm{~h}$ p.i. (B). PI cells at passage $25(\mathrm{C})$ and $65(\mathrm{D})$ at $48 \mathrm{~h}$ after subcultivation. PK-15 cells infected with virus $(0.1 \mathrm{~m} . \mathrm{o}$. . $)$ from PI cells at passage $25(\mathrm{E})$ and $65(\mathrm{~F})$ at $48 \mathrm{~h}$ p.i. Cells were immunostained with the NP MAb 29.9. Magnification 400 $\times$. 

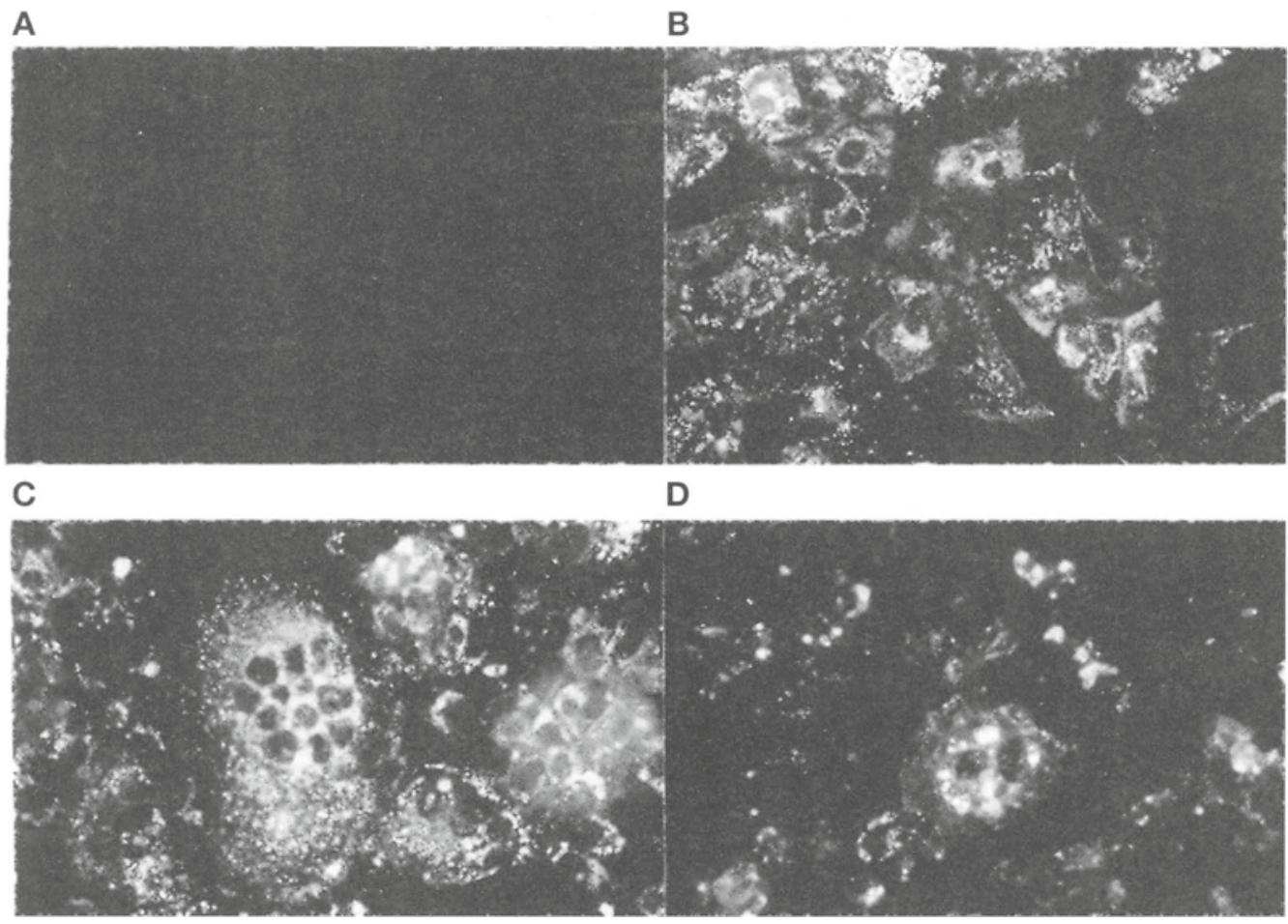

Figure 4. Detection of haemagglutinin-neuraminidase $(\mathrm{HN})$ protein in LPMV wild type and persistently infected cells by immunofluorescence. Mock infected PK-15 cells (A). Wild type infected (0.1 m.o.i.) PK-15 cells at $48 \mathrm{~h}$ p.i. (B). PI cells at passage 25 (C) and 65 (D) at $48 \mathrm{~h}$ after subcultivation. Cells were immunostained with the $\mathrm{HN}$ MAb 32.11. Magnification $400 \times$.

cells measured by HA (HA titer of 8 compared to 64). However, the infectious titre was at least 3 logs lower in virus recovered from the PI cells compared to the LPMV infected cells. The virus from the PI cells (passages 25 and 65) could infect PK-15 cells, but showed a reduced ability to spread within the culture. When PK-15 cells were infected with $0.1 \mathrm{Ffu}$ of virus released from PI cells or wild type virus and incubated for 2 days, only $10 \%-20 \%$ of the cells were positive for viral antigen compared to $100 \%$ in the wild type infection (Fig. 3E, F).

The results of the characterisation of the porcine rubulavirus (LPMV) persistently infected cells are summarised in Table 1.

\section{Discussion}

The ability of paramyxoviruses to establish persistent infections is well known, and the importance of such infections for the epidemiology of the virus has been reviewed (Randall \& Russell 1991). Persistent infections have proven relatively easy to establish in vitro and these infections have contributed to the understanding of molecular events associated with the growth of paramyxoviruses. Various mechanism(s) behind the establishment and maintenance of persistent infections have been proposed (Schneider-Schaulies et al. 1994b).

Porcine rubulavirus infects cell lines of different species (Moreno-López et al. 1986), and es- 
Table 1. Properties of the porcine rubulavirus (LPMV) persistent infection in PK-15 cells.

\begin{tabular}{|c|c|c|c|c|}
\hline & PK-15 & $\begin{array}{l}\text { PK-15 Wild type } \\
10 \text { m.o.i. }\end{array}$ & $\begin{array}{l}\text { PK-15 PI } \\
\text { pass. } 25\end{array}$ & $\begin{array}{l}\text { PK-15 PI } \\
\text { pass. } 65\end{array}$ \\
\hline Growth rate ${ }^{\mathrm{a}}$ & $20 \mathrm{~h}$ & nd & $40 \mathrm{~h}$ & $40 \mathrm{~h}$ \\
\hline $\mathrm{CPE}^{\mathrm{b}}$ & - & ++ & + & + \\
\hline Syncytium formation ${ }^{c}$ & - & frequent & frequent & frequent \\
\hline HAD $(\%)$ & - & $\sim 100$ & $\sim 100^{\mathrm{d}}$ & $\sim 100^{\mathrm{d}}$ \\
\hline \multicolumn{5}{|l|}{ Viral antigens: } \\
\hline NP (\%) & - & $\sim 100$ & $\sim 100$ & $\sim 100$ \\
\hline $\mathrm{HN}(\%)$ & - & $\sim 100$ & $\sim 100$ & $\sim 100$ \\
\hline Anti-LPMV serum treatment & - & protected & not cured & not cured \\
\hline IFN-production $(\mathrm{u} / \mathrm{ml})$ & 0 & 0.5 & 0 & 0 \\
\hline VSV infection ${ }^{\mathrm{e}}$ & lysis & nd & lysis & lysis \\
\hline $\mathrm{HA}$ & 0 & 64 & 8 & 8 \\
\hline Titer (Ffu/ml) & - & $10^{8}$ & $10^{5}$ & $10^{5}$ \\
\hline Superinfection & nd & nd & resistant & resistant \\
\hline
\end{tabular}

nd. Not done.

a. Estimated from series of time laps photographs.

b. +++ complete destruction of monolayer.

+ few cells undergo destruction, cells grow to confluence.

- none.

c. Quite abundant in every viewfield, passage 65 sometimes fewer and fewer nuclei/cell.

d. All cells adsorb early after subcultivation. Less than $100 \%$ adsorb toward confluence.

e. All cells underwent lysis within $24 \mathrm{~h}$.

tablishment of persistent infections appear to be easy in most of them (Moreno-López, unpublished results).

In this study, we established and characterised a persistent infection in porcine kidney cells. Less than $5 \%$ of the lytically infected cells will survive the primary infection and can be grown further as a confluent monolayer. These cells produce both viral antigens and virus particles. The initial establishment of persistently infected cells probably involves a selection of both virus and cell variants. That a subpopulation of host cells might be selected is underscored by the fact that different sources of PK15 cells show remarkable differences in their capability to replicate porcine rubulavirus ( $\mathrm{Mo}$ reno-López et al. 1986).

The PK-15 cell cultures used here had a growth doubling time of about $20 \mathrm{~h}$. Both passages of the PI cell cultures had a growth rate of about $40 \mathrm{~h}$, indicating that the presence of the virus exerts constraints on host cell growth or that cells with a slower growth rate were selected during the establishment of the persistent state. CPE was evident, mainly seen as vacuoles and syncytium formation, but no or very few cells lysed. The syncytia in persistently infected cells were more prominent at passage 25 , characterised by higher occurrence and more nuclei per syncytium.

All PI cells in a subconfluent culture adsorb chicken erythrocytes. However, the ability to adsorb is reduced to about $50 \%-75 \%$ in a culture about to reach confluence. Both the NP and the $\mathrm{HN}$ proteins were detected in all PI cells by immunofluorescence, the pattern resembling lytic infection, although less intense.

The persistently infected cell cultures were re- 


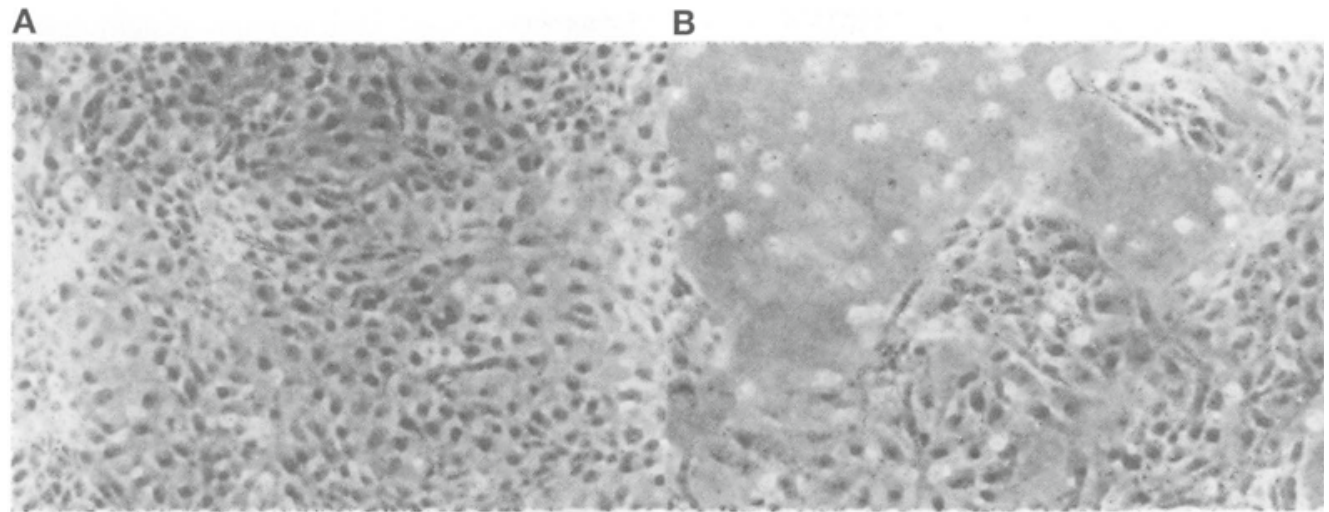

C

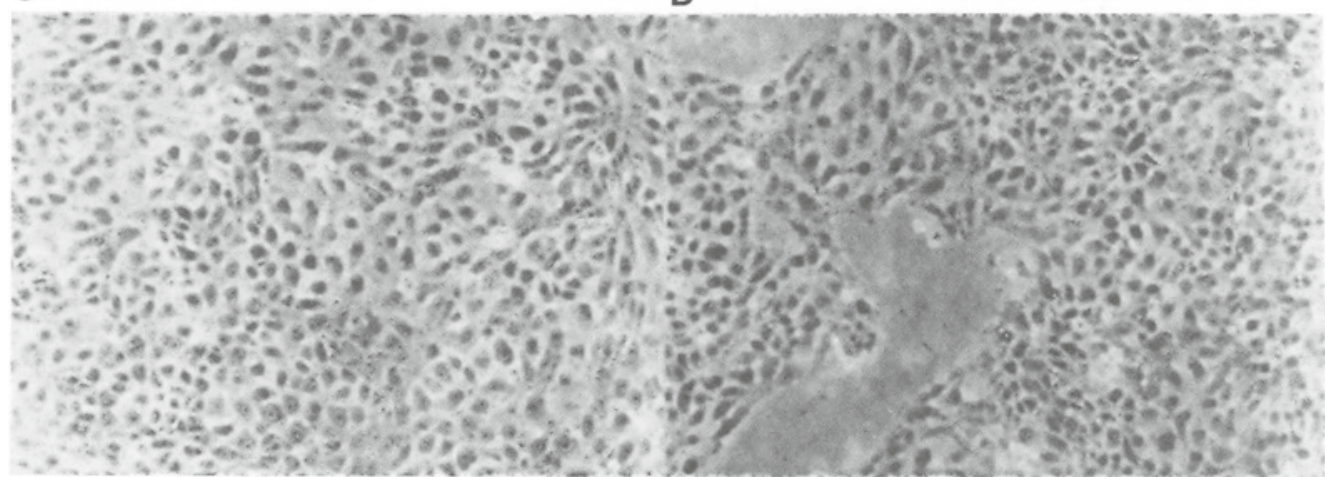

E

$\mathbf{F}$

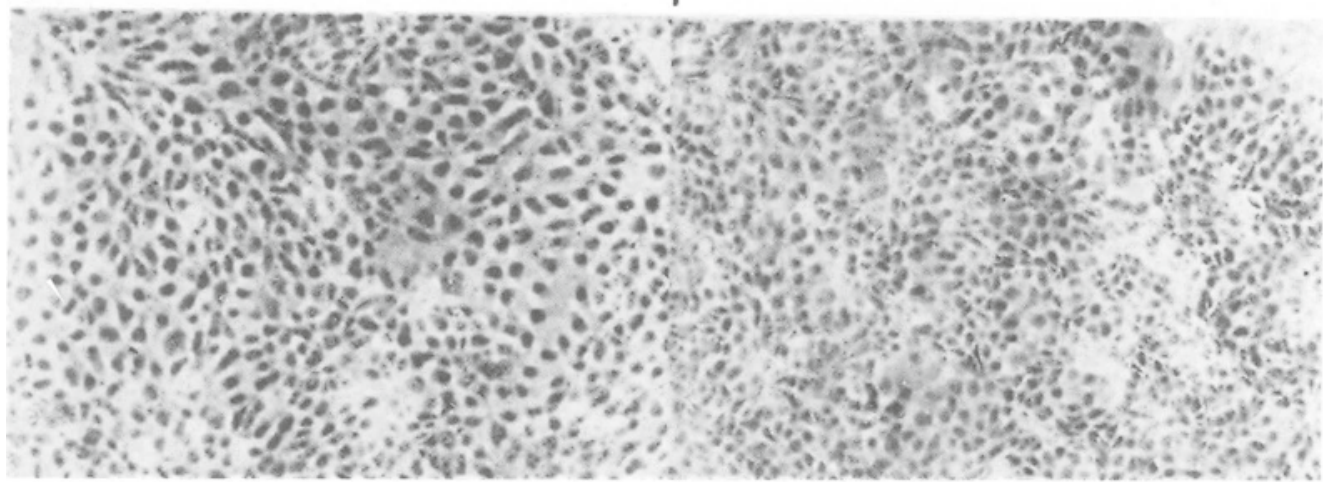

Figure 5. Superinfection of persistently infected (PI) cells. Mock infected PK-15 cells (A). Wild type infected PK-15 cells (10 m.o.i.) $48 \mathrm{~h}$ p.i. (B). PI cells at passage 25 (C) and 65 (D) at $120 \mathrm{~h}$ after subcultivation. LPMV superinfected (10 m.o.i.) PI cells of passage $25(\mathrm{E})$ and $65(\mathrm{~F})$ at $120 \mathrm{~h}$ p.i. Magnification $100 \times$. 
sistent to superinfection, i.e. no increase in $\mathrm{CPE}$, syncytium formation or haemadsorption could be detected after infection with 10 m.o.i. of LPMV, although they were fully susceptible to VSV infection. Measurements of the level of interferon, which has been implicated in establishing persistent infections (Carrigan \& $\mathrm{Ka}$ bacoff 1987, Schneider-Schaulies et al. 1994a) proved negative. An attempt to cure the cells by incubation with virus neutralising antibodies for 5 weeks was unsuccessful. Thus, the infection fulfilled all criteria of a persistent infection (Holland et al. 1980), i.e. it is not a low grade lytic infection, where virus resides in just a portion of the cells and infects new ones at the same rate as they are produced. Such cultures are unstable and have a high tendency to cure themselves (Holland et al. 1980).

Persistently infected cells at both passages released virus into the medium, but with titers 3 logs lower than that released during a wild type infection. On comparison of the haemagglutination activity of the virus from the PI cells with that from wild type infection, the HA titers of PI cells were only 8 fold lower. This indicates that most of the virions produced during the persistent infection are non infectious. This could be explained by a presence of subgenomic RNAs, that have the ability to interfere with the replication of the standard virus. Experiments to verify this is currently underway. Furthermore, the released virus might be useful for immunisation applications. Many attenuated paramyxoviruses used as vaccines have been shown to contain DI particles (Calain \& Roux 1988, Bellocq et al. 1990). Preparations of DI particles also have prophylactic properties (Jones \& Holland 1980, Noble \& Dimmock 1994).

In vivo LPMV persistent infection in pigs has not been investigated. Subclinically infected pigs are the main sources of the disease. In badly managed herds sometimes older pigs are taken ill, showing mild nervous system disorders (Stephano \& Gay 1985). These animals could theoretically be targets for persistent infections. If this would be the case, neurones, by lacking expression of MHC class I molecules, could provide a compartment in which host immune surveillance could be evaded (Joly et al. 1991, Wharton \& Nash 1993). In acutely infected pigs, LPMV RNA has been shown in neurones by in situ hybridisation (Kennedy personal communication). Additionally, in experimentally infected pigs that recovered from an acute infection, LPMV RNA was detected in brain material by RT-PCR (Bergvall personal communication). Furthermore, the amount of detectable RNA could be increased by immunosuppression. The establishment of persistent porcine rubulavirus infected cells and the possibility to experimentally induce persistent infection of pigs could be an interesting model system for paramyxovirus persistence, with special emphasis on mumps virus because of its relatedness.

\section{Acknowledgements}

Thanks are due to Eva Wattrang (IFN-work), Lisbeth Gerd Fuxler (VSV work), Anita Sundquist and KjellOlov Grönvik (hybridoma work), Mikael Berg (critical reading and discussion) and Leif Oxburgh (linguistic revision). This work was supported by grants from the Swedish International Development Cooperation Agency and the Swedish Council for Forestry and Agricultural research.

\section{References}

Artursson $K$, Lindersson $M$, Varela $N$, Scheynius A, Alm GV: Interferon- $\alpha$ production and tissue localization of interferon- $\alpha / \beta$ producing cells after intradermal administration of aujesky's disease virus-infected cells in pigs. Scand. J. Immunol., 1995, 41, 121-129.

Bellocq C, Mottet G, Roux L: Wide occurrence of measles virus subgenomic RNAs in attenuated live-virus vaccines. Biologicals 1990, 18, 337343. 
Berg M, Hjertner B, Moreno-López J, Linné T: The $\mathrm{P}$ gene of the porcine paramyxovirus LPMV encodes three possible polypeptides $\mathrm{P}, \mathrm{V}$ and $\mathrm{C}$ : the P protein mRNA is edited. J. Gen. Virol., 1992, 73, 1195-1200.

Berg M, Sundqvist A, Moreno-López J, Linné T: Identification of the porcine paramyxovirus LPMV matrix protein gene: Comparative sequence analysis with other paramyxoviruses. J. Gen. Virol., 1991, 72, 1045-1050.

Calain C, Roux L: Generation of measles defective interfering particles and their presence in a preparation of attenuated live-virus vaccine. J. Virol., 1988, 62, 2859-2866.

Carrigan DR, Kabacoff CM: Identification of a nonproductive, cell-associated form of measles virus by its resistance to inhibition by recombinant human interferon. J. Virology, 1987, 61, 19191926.

Dinter Z: Diagnostic virology: review of methods at the National Veterinary Institute. 1989 (MorenoLópez J, ed.), Swedish University of Agricultural Sciences, National Veterinary Institute, Uppsala, Sweden.

Harlow E, Lane D: Antibodies: A laboratory manual. 1988, Cold Spring Harbor Laboratory, Cold Spring Harbor, New York.

Holland JJ, Kennedy IT, Semler BL, Jones CL, Roux $L$, Grabau EA: Defective interfering RNA viruses and the host-cell response. Comprehensive Virology 16 (Fraenkel-Conrat $\mathrm{H}$ and Wagner RR, eds.), 1980, pp 137-192, Plenum Press, New York.

Joly E, Mucke L, Oldstone MBA: Viral persistence in neurons explained by lack of major histocompatibility class I expression. Science, 1991, 253, 1283-1285.

Jones CL, Holland JJ: Requirements for DI particle prophylaxis against VSV infection in vivo. J. Gen. Virol., 1980, 49, 215-20.

Moreno-López J, Correa-Girón P, Martinez A, Ericsson A: Characterization of a paramyxovirus isolated from the brain of a piglet in Mexico. Arch. Virol., 1986, 91, 221-231.

Moscona A: Defective interfering particles of human parainfluenza virus type 3 are associated with persistent infection in cell culture. Virology, 1991, 183, 821-824.

Murphy DG, Dimock K, Kang Y: Viral RNA and protein synthesis in two LLC-MK ${ }_{2}$ cell lines persistently infected with human parainfluenza type 3 . Virus Res., 1990, 16, 1-16.
Noble S, Dimmock NJ: Defective interfering type A equine influenza virus $(\mathrm{H} 3 \mathrm{~N} 8)$ protects mice from morbidity and mortality caused by homologous and heterologous subtypes of influenza A virus. J. Gen. Virol., 1994, 75, 3485-3491.

Randall RE, Russel WC: The paramyxoviruses: Paramyxovirus persintence: Consequences for host and virus (D.W. Kingsbury, Ed.), 1991, Chap. 11. Plenum Press, New York.

Re GG: The paramyxoviruses: Deletion mutants of paramyxoviruses (D.W. Kingsbury, Ed.), 1991, Chap. 10. Plenum Press, New York.

Reed $L$, Muench $H$ : A simple method of estimating fifty per cent end points. Am. J. Hygiene, 1938, 27, 493-497.

Rima B, Alexander DJ, Billeter MA, Collins PL, Kingsbury DW, Lipkind MA, Nagai Y, Örvell C, Pringle $C R$, ter Meulen V: Virus taxonomy, 6th report of the international comittee on taxonomy of viruses. Arch. Virol. Suppl. 10, 1995, 268-274.

Schneider-Schaulies S, Schneider-Schaulies J, Schuster A, Bayer M, Pavlovic J, ter Meulen V: Cell type specific MxA-mediated inhibition of measles virus transcription in human brain cells. J. Virol., 1994a, 68, 6910-6917.

Schneider-Schaulies S, Schnorr J-J, Dunster LM, Schneider-Schaulies J, ter Meulen V: The role of host factors in measles virus persistence. Sem. Virol., 1994b, 5, 273-280.

Stephano HA, Gay GM: El syndrome del ojo azul en granjas engordadoras. Mem 19th congr assoc mex vet esp cerdos. Merida, 1985, pp. 71-74.

Stephano HA, Gay GM, Ramirez TC: Encephalomyelitis, reproductive failure and corneal opacity (blue eyes) in pigs, associated with a paramyxovirus infection. Vet. Rec., 1988, 122, 6-10.

Sundqvist A, Berg M, Hernandez-Jauregui P, Linné T, Moreno-López J: The structural proteins of a porcine paramyxovirus (LPMV). J. Gen. Virol., 1990, 71, 609-613.

Sundqvist A, Berg M, Moreno-López J, Linné T: The hemagglutinin-neuraminidase gene of the porcine paramyxovirus LPMV: Comparison with other paramyxoviruses revealed the closest relationship to Simian virus 5 and mumps virus. Arch. Virol., 1992, 122, 331-340.

Wharton $S B$, Nash AA: Virus-cell interactions in the nervous system and the role of the immune response. Curr. op. neurobiol., 1993, 3, 768-772.

Örvell C: The reactions of monoclonal antibodies with structural proteins of mumps virus. J. Immunol., 1984, 132, 2622-2629. 


\section{Sammanfattning}

Etablering och karakterisering av en porcin rubulavirus persistent infektion i svinnjurceller.

Porcint rubulavirus LPMV (paramyxoviridae) ger upphov till respiratoriska och neurologiska infektioner. En persistent LPMV infektion av svinnjurceller har etablerats och karaktäriserats efter 25 och 65 passager, det senare efter ett års kontinuerlig odling. Alla celler är infekterade och ej mottagliga för en LPMV lytisk infektion. Den persisterande infektionen går ej att bota genom att odla cellerna $\mathrm{i}$ närvaro av neutraliserande antikroppar. Viruspartiklar utsöndras kontinuerligt i mediet och kan påvisas med hemagglutination. Titrering på njurceller visade en låg infektionstiter, $10^{-3}$ gånger lägre än vid en lytisk infektion. Spridning av infektionen I en cellmatta är starkt begränsad jämfört med en lytisk infektion, och cellmattan föstörs ej. Detta kan indikera förekomsten av defekta interfererande partiklar. Denna persisterande infektion kan användas för att producera defekt virus för immuniseringsförsök, eventuell profylax och studier av molekylära processer under paramyxovirus infektioner.

(Received February 27, 1997; accepted March 19, 1997).

Reprints may be obtained from: B. Hjertner, Department of Veterinary Microbiology, Section of Virology (Unit of Molecular Virology), Biomedical Centre, Swedish University of Agricultural Sciences, Box 585, S-751 23 Uppsala, Sweden. E-mail: Hjertner@vmm.slu.se, tel: +46-18-4714030, fax: +46-18-4714572. 